\title{
Effects of flooding on the spatial distribution of soil seed and spore banks of native grasslands of the Pantanal wetland
}

\author{
Patricia Carla de Oliveira ${ }^{1 \star}$, José Marcelo Domingues Torezan² and Catia Nunes da Cunha ${ }^{1}$
}

Received: February 4, 2015. Accepted: April 22, 2015

\begin{abstract}
To better understand the role that flooding plays in shaping plant communities of native floodable grasslands of the Pantanal and to characterize the spatial distribution of plants, we present the results of a survey of soil seed and spore banks using the seedling emergence method. We hypothesized that terrain subjected to the deepest and longest flooding should have higher propagule abundance and richness. The species composition and distribution of seeds and spores in the soil were assessed at five sites using three sampling positions at each according to inundation intensity. In each sample position $2 \mathrm{~cm}$-thick soil samples were collected in quadrats to a depth of $10 \mathrm{~cm}$. Litter was also collected as an independent layer. Sample monitoring in the greenhouse resulted in the emergence of 5489 seedlings, or 6353 propagules. $\mathrm{m}^{-2}$. Both the litter layer and the deepest soil layer had low abundances. A total of forty-four morphospecies (16 families) were recorded. Both seedling abundance and species richness were concentrated in the more floodable center sections. Isoetes pedersenii, Eleocharis minima, Sagittaria guayanensis, Rotala mexicana, Eleocharis plicarhachis, and Panicum laxum were the most abundant species. The species composition and spatial distribution of the propagule bank suggests that flooding plays a crucial role in seasonal vegetation dynamics in Pantanal wetlands, mediated by the ability of the soil to host seeds and spores during dry season.
\end{abstract}

Keywords: Eleocharis minima, Eleocharis plicarhachis, flooding, grasslands, Isoetes pedersenii, Panicum laxum, Rotala mexicana, Sagittaria guayanensis, soil seed and spore bank, spatial distribution

\section{Introduction}

Soil seed banks are important to plant communities because they ensure the persistence of vegetation over time (Baskin \& Baskin 2001), they facilitate the ability to respond to disturbance (Thompson 1992; Valk 2013), and they provide the main source of new recruits (Cheke et al. 1979; Jalili et al. 2003). Moreover, a plant community is only completely known when the composition of the soil seed bank is assessed along with that of the aboveground vegetation (Rice 1989), because these frequently differ in species composition, abundance and richness (Ungar \& Woodell 1996; Hölzel \& Otte 2001; Jalili et al. 2003).

Soil seed banks change as a function of several factors, such as distance from seed sources (Hölzel \& Otte 2001) and aboveground vegetation (Jalili et al. 2003), and the physical and chemical attributes of the soil (Maia et al. 2004; Pagotto et al. 2011). Flooding can also have a strong influence on seed bank structure (Hölzel \& Otte 2001; Capon \& Brock 2006; Bao et al. 2014) because of two primary factors, water flux and soil hydrology. Water flux serves as a dispersal agent (Middleton 2000) bringing new propagules to the bank and soil hydrology chiefly determines both seed recruitment (Peterson \& Baldwin 2004; Bao et al. 2014) and seedling establishment (Prado et al. 1994; Rebellato \& Nunes da Cunha 2005). These factors ultimately affect the composition of species that will produce seeds and spores that will be incorporated into the soil bank. Therefore, analysis of soil seed bank composition of sites with different flooding regimes can provide a way to investigate the influence that flooding has in soil seed bank formation (Hölzel \& Otte 2001).

In the Brazilian Pantanal, the major continental freshwater wetland of the world, flood-prone savannic grasslands are one of the most common vegetation components, covering up to $57 \%$ of wetland landscapes (Abdon et al. 1998; Silva \& Abdon 1998). The dominance of graminoid herbs (mainly Poaceae and Cyperaceae) in these grasslands has facilitated their conversion into pastures for cattle ranching, the main economic activity in the Brazilian Pantanal (Cardoso et al. 2000). Thus, research on the soil seed banks in these grasslands will help to better understand their

\footnotetext{
${ }^{1}$ Departamento de Botânica e Ecologia, Instituto de Biociências, Universidade Federal de Mato Grosso. Fernando Correa da Costa, s/n, CCBS-II, Boa Esperança. 78060-900. Cuiabá, MT, Brazil

${ }^{2}$ Laboratório de Biodiversidade e Restauração de Ecossistemas, Universidade Estadual de Londrina, P.O. Box 6001, 86.051-990. Londrina, PR, Brazil

*Corresponding author: patiranjak@yahoo.com.br
} 
wetland ecology (Fenner \& Thompson 2005) and further environmentally sound pasture management practices (Tuffi-Santos et al. 2004).

Knowledge regarding soil seed banks in Brazilian tropical wetlands is far from that that has been accumulated for some old-world regions (Thompson et al. 1997). In fact, the present study is one of the few contributions on soil seed banks in the Brazilian Pantanal. Herein we describe the soil spore and seed bank composition and analyze the spatial distribution of species abundance and richness for a protected area of the Brazilian Pantanal. Furthermore, since inundation can be an important factor in determining an established plant community, as extensively reported (Schessl 1999; Rebellato \& Nunes da Cunha 2005; Nunes da Cunha et al. 2006), it is expected to have the same influence on soil seed banks. We hypothesize, therefore, that higher seed abundance and richness will be found in the lower portions of the grassland terrain that experience the deepest and longest flooding.

\section{Material and Methods}

\section{Study sites}

Samples were collected in August 2007, during the dry season when the grasslands were in their terrestrial phase. Collecting was performed at five sites inside RPPN - SESC Pantanal, a private nature reserve of $1066.44 \mathrm{~km}^{2}$ owned by "Serviço Social do Comércio" and located between $16^{\circ}$ and $17^{\circ} \mathrm{S}$ and $56^{\circ}$ and $57^{\circ} \mathrm{W}$ in Barão de Melgaço, state of Mato Grosso, Brazil (Fig. 1). The climate type is Aw according to the Köppen (1948) system, with dry winters and rainy summers. Annual rainfall ranges from 1000 to 1500 mm.year ${ }^{-1}$ and annual average temperature oscillates between $22^{\circ} \mathrm{C}$ and $32^{\circ} \mathrm{C}$ (Hasenack et al. 2003). Rainy months are from October to April and dry months from May to September (Hasenack et al. 2003). All sampling sites were floodable native grasslands (Fig. 1 in supplemental material), locally called "Campinas", and are subjected to nearly six months of flooding (from December to May). They are typically circular shape and possess a gradual slope down to the center. During the terrestrial phase, these floodable grasslands are dominated by genera of Poaceae, such as Andropogon, Imperata, and Paspalum, and are surrounded by "Cordilheiras", paleo-levees that are higher, less or nonfloodable terrain with denser tree vegetation (Nunes da Cunha et al. 2006; 2007).

The grasslands of RPPN - SESC Pantanal range in size from 100 to 300 meters in diameter. Their hydrology is similar to that of temporary shallow lakes, with the deepest water and longest period of flooding being located in the center. Peak inundation occurs mainly in March (Silva \& Figueiredo 1999), and is caused by both rainfall accumulation and elevated phreatic level, but is also contributed to by water invasion from the Cuiabá River.

\section{Field and laboratory procedures}

To investigate the role of flooding in determining soil propagule bank structure and spatial pattern, soil samples from different positions along flood gradients and from different depths in the soil were evaluated using the seedling emergence method (Thompson et al. 1997). In August 2007, during the dry season and terrestrial phase, five sites were randomly chosen from among the 20 grassland fields occurring in the nature reserve. A horizontal distribution of flood intensity was established at each site by taking soil samples at three positions (border, middle and center) with a distance between samples ranging from $50 \mathrm{~m}$ to $100 \mathrm{~m}$ (Fig. 1 in supplemental material), depending on grassland diameter (min. 100; max. 300m). In order to establish a
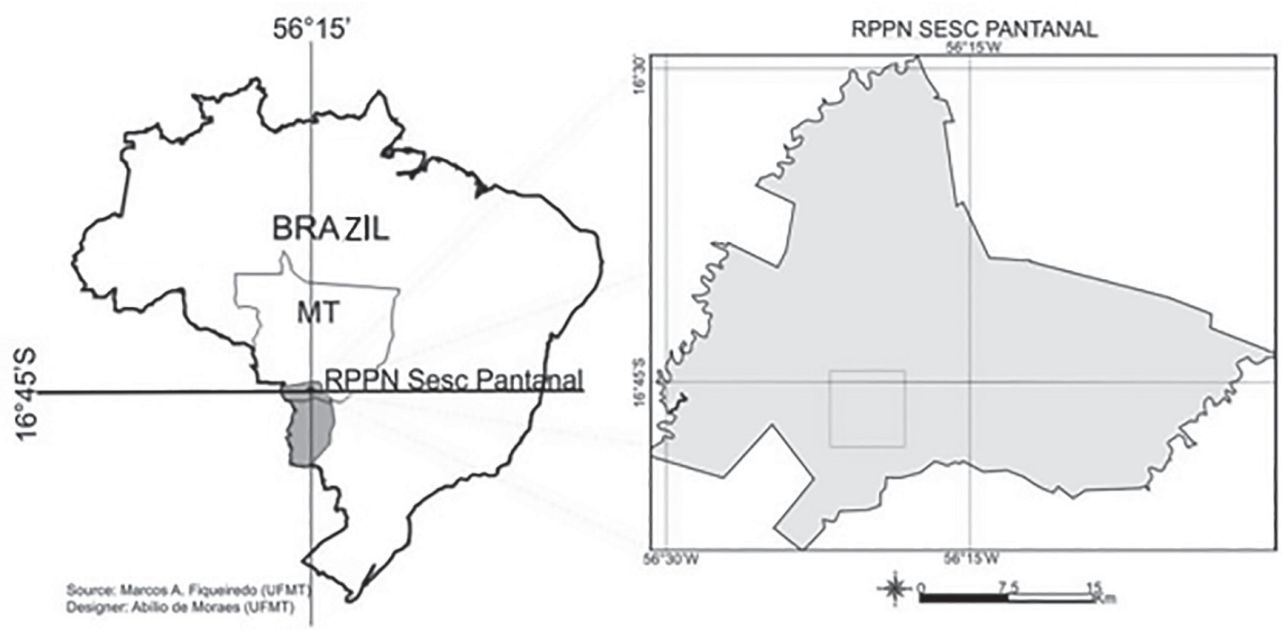

Figure 1. Location of study sites in a protected area of the Pantanal (RPPN SESC Pantanal). The larger square shows the protected area, whereas the smaller square shows where grasslands are concentrated. 
vertical distribution of seeds and spores stocked in the soil, soil samples were collected using a graduated metal box measuring $0.24 \times 0.24 \times 0.3 \mathrm{~m}$, and separated into $2 \mathrm{~cm}$-thick layers (up to $10 \mathrm{~cm}$ in depth) plus the litter layer. In March 2008 , during the aquatic phase, flood level was measured at each soil sample position at all five sites, using water level as a measure of flood intensity.

Soil samples were air-dried in the dark and then sifted ( $8 \mathrm{~mm}$ mesh) to eliminate vegetative propagules. The samples were then placed into $0.25 \times 0.12 \times 0.05 \mathrm{~m}$ transparent plastic trays with the bottom covered with a $1 \mathrm{~cm}$ layer of washed sand; the soil samples added up to $2 \mathrm{~cm}$ thus reaching a total height of up to $3 \mathrm{~cm}$ in the trays.

In September 2007, the trays were placed in a greenhouse, with 10 additional trays containing only sand as a control for possible greenhouse-borne seed and spore contamination.

\section{Monitoring}

Humidity was maintained by active irrigation once per day. Seedlings were documented and counted every two weeks; the first seedlings were recorded in October 2007 and the monitoring extended from September to June 2008 (ten months). Preliminary identification of seedlings was performed on the basis of general morphotypes prior to their removal from the trays. They were then individually labeled and left to grow until the development of vegetative characters sufficient for final identification. Whenever possible, seedlings were identified to species through direct comparisons with specimens in the plant collections of the Universidade Federal de Mato Grosso Herbarium, and with the aid of botanical experts.

In order to stimulate additional germination events during the last three months of monitoring, all samples were submitted to the following procedures that aimed to simulate the environmental conditions of light exposure followed by flooding (i.e. total submersion): (1) in the seventh month the soil in the trays was overturned in order to bring to surface any seeds deprived of light lying on the bottom; and (2) in the last two months (months nine to the ten), the soil samples were completely submerged in water.

\section{Data analyses}

Differences in flood intensity among positions (border, middle and center) were verified by an analysis of variance (ANOVA) of water column height, followed by a Tukey test, both done after checking for normality and homoscedasticity of the residuals (Zar 1999).

Abundance and richness were adopted as parameters to compare the spatial distribution of the soil seed bank and spore bank under different inundation levels. Generalized linear mixed models (GLMM) with Poisson distribution were performed on abundance and richness to evaluate the influence of inundation on these banks. Positions (assumed as inundation intensity) and layers were treated as fixed variables. Position values as well as interaction values were considered because they represent inundation influence. Significance level for all analyses was 5\%. Both ANOVA and GLMM were performed by R program (version Ri386 3.1.1).

A scale for species abundance was adopted: species occurring in less than $10 \%$ of the samples were considered "rare"; species between 10 and 25\% were considered "near abundant"; and over $25 \%$ were considered "common" (Butler \& Chazdon 1998).

\section{Results and discussion}

\section{Soil seed and spore bank partial composition}

Even though our sample was based on a single sampling method from a single collection event during the terrestrial (dry) phase, we found abundant seeds and spores in the banks during the 10-month monitoring period (with $98.9 \%$ of the seedlings emerging in the first 5 months). In total, 5489 seedlings emerged, which corresponds to 6353 propagules. $\mathrm{m}^{-2}$. No further germination was achieved by overturning the soil samples or by simulating inundation, suggesting that the monitoring interval and the procedures were sufficient. No seedlings emerged from the control trays.

Germination was concentrated towards the beginning of the experiment, as was expected since the same was reported for samples obtained from other, quite different Brazilian ecosystems (Araújo et al. 2001; 2004; Costa \& Araújo 2003). The extensive amount of germination in response to the change from field (dry soil) to greenhouse conditions (wet soil samples) suggests that those seeds only needed their required germination conditions to germinate, thus characterizing them as quiescent and non-dormant seeds (Baskin \& Baskin 2004; Borghetti 2004). The overall propagule density ( 6.3 thousand seeds and spores. $\mathrm{m}^{-2}$ ) could be considered high but if the spores are excluded from the data the density drops to 2.6 thousand seeds. $\mathrm{m}^{-2}$, a value lower than those reported for other wetlands such as the Everglades (3.7 thousand seeds. $\mathrm{m}^{-2}$ ) (Valk \& Rosburg 1997), and pothole lakes in United States (3.6 thousand seeds ${ }^{-2}$ ) (Baskin \& Baskin 2001). Sampling interval and season of sampling can influence the results of soil seed and spore bank surveys. Sampling just before or just after a dispersal event of a species that forms a transient seed bank can lead to biased seed density estimates (Simpson et al. 1989; Jalili et al. 2003). Thus, both the density and species richness figures presented here may be underestimates since sampling took place at a single time.

Forty-four morphospecies were found among the germinating seeds (36 identified to species level; Tab. 1 in supplemental material). However, inferring seed and spore bank composition using the seedling emergence method can lead to underestimates of species richness because, 
Table 1. Species composition for soil seed and spore banks in floodable grasslands of the Pantanal wetland.

\begin{tabular}{lcc}
\hline \multicolumn{1}{c}{ Species } & Family & Occurrence (\%) \\
\hline Isoetes pedersenii & Isoetaceae & 57.90 \\
Eleocharis minima & Cyperaceae & 9.00 \\
Sagittaria guayanensis & Alismataceae & 5.09 \\
Rotala mexicana & Scrophulariaceae & 3.92 \\
Eleocharis plicarhachis & Cyperaceae & 3.50 \\
Panicum laxum & Poaceae & 2.72 \\
Setaria geniculata & Poaceae & 2.37 \\
Eleocharis geniculata & Cyperaceae & 2.26 \\
Cyperus haspan & Cyperaceae & 1.90 \\
Ludiwia octovalvis & Onagraceae & 1.46 \\
Ludwigia inclinata & Onagraceae & 1.22 \\
Thirty-three other species & & 8.65 \\
(under 1\% each one) & & $\mathbf{1 0 0}$ \\
Total & & \\
\hline
\end{tabular}

among other factors, the experimental conditions may have been marginal for the germination of some species (Thompson et al. 1997; Baskin \& Baskin 2001). The most common species among the germinating plants were Isoetes pedersenii (Isoetaceae), Eleocharis minima (Cyperaceae), and Sagittaria guayanensis (Alismataceae). Among the 5489 emerged seedlings, the vast majority $(\sim 58 \%)$ were the fern Isoetes pedersenii (Isoetaceae) (Tab. 1), with densities of 3680 spores. $\mathrm{m}^{-2}$. The high relative abundance of Isoetes pedersenii was responsible for the relative abundance of the other species to be considered rare, both in position and in layer of the grasslands (Tabs. 2, 3). Most species showed a relative abundance below $1 \%$ (Tab. 1).

If only seed plants were considered in the analysis, only two species (Eleocharis minima, 571 seeds.m ${ }^{-2}$, and Sagittaria guayanensis, 318 seeds. $\mathrm{m}^{-2}$ ) would have been moved from rare to near abundant. Whether ferns are included in the analysis or not, it is clear that the soil propagule bank in the floodable grassland sites is composed predominantly of rare species.

Sixteen botanical families were found among the germinating seeds. Isoetaceae (ferns), Cyperaceae, Alismataceae, Scrophulariaceae, Poaceae, and Onagraceae encompassed $92.4 \%$ of the sampled species abundance (Tab. 1). Some of these seed plant families seem to be prevalent in soil seed banks. Cyperaceae, Poaceae and Scrophulariaceae were widely found in seed banks from native pastures in southern Brazil (Maia et al. 2004) and in agro-ecosystems established over floodplains in the Amazon region (Leal et al. 2006). Poaceae and Cyperaceae comprised a great portion of the seed banks in Cerrado sites (Brazilian savanna) (Ikeda et al. 2008).

Despite the dry phase established plant community being dominated by the Poaceae genera Andropogon, Imperata, and Paspalum, almost all of the species that emerged from the soil samples in this experiment were aquatic macrophytes commonly listed in aquatic floristic checklists for the Brazilian Pantanal (Schessl 1999; Pott \& Pott 2000a; b; Rebellato \& Nunes da Cunha 2005). With the exception of Paspalum lenticulare, for which only three seedlings emerged, none of the terrestrial-phase dominant species were found among the germinating seeds. Such a mismatch between the dry season grass cover and the seed bank composition has been reported by other authors (López-Mariño et al. 2000; Jalili et al. 2003; Melo et al. 2007; Valk 2013) and may be related to the maintenance of only a transient bank of grasses and to the strong seasonality of such banks (Thompson et al. 1997). Several repeated samples over short time intervals must be used to sample for these species (Baskin \& Baskin 2001).

Some interesting questions emerge from these observations: What is the main population maintenance strategy of dry season dominant species? To what extent is their maintenance strategy dependent on seed banks? To address these questions, the phenology and seed viability of the dry season dominant species need to be investigated.

\section{Spatial distribution of soil seed and spore bank and hypothesis testing for flooding intensity}

Average water level $( \pm \mathrm{sd})$ showed an increase in water depth (and thus flooding intensity) from the border to the middle to the center with $16.8 \mathrm{~cm}( \pm 4.15), 39.4 \mathrm{~cm}$ $( \pm 4.45)$, and $46.2 \mathrm{~cm}( \pm 6.61)$, respectively. The differences were significant between border and middle $(\mathrm{F}=44.03$, $\mathrm{p}<0.0001$; Tukey, $\mathrm{p}<0.01$ ) and border and center (Tukey, $\mathrm{p}<0.01)$. The border was subjected to the least intense flooding.

\section{Abundance}

Seeds and spores were highly concentrated (Fig. 2A-C; Tab. 2) in the center region of the floodable grassland sites (73\%). Middle samples accounted for $21 \%$ and the border for only $6 \%$ of the total abundance. The distribution of abundance among layers was strongly influenced by flood intensity (i.e. grassland position) as detected by the interaction term of the GLMM $(\mathrm{z}=-0.068, \mathrm{p}<0.001)$.

Seed and spore concentration in the center of grassland sites can be related to long-lasting flooding (Hölzel \& Otte 2001; Capon \& Brock 2006), which could lead to a higher number of plant species completing life cycles and thus producing more seeds (Casanova \& Brock 2000; Peterson \& Baldwin 2004). Moreover, inundation can influence the distribution of soil seed and spore banks by acting as a dispersal agent for many plant species (Pagotto et al. 2011; Silveira \& Weiss 2014). Considering water flux as the main dispersal agent, the concave relief on these grasslands, even with a soft slope, would also favor seed accumulation in the center position. 

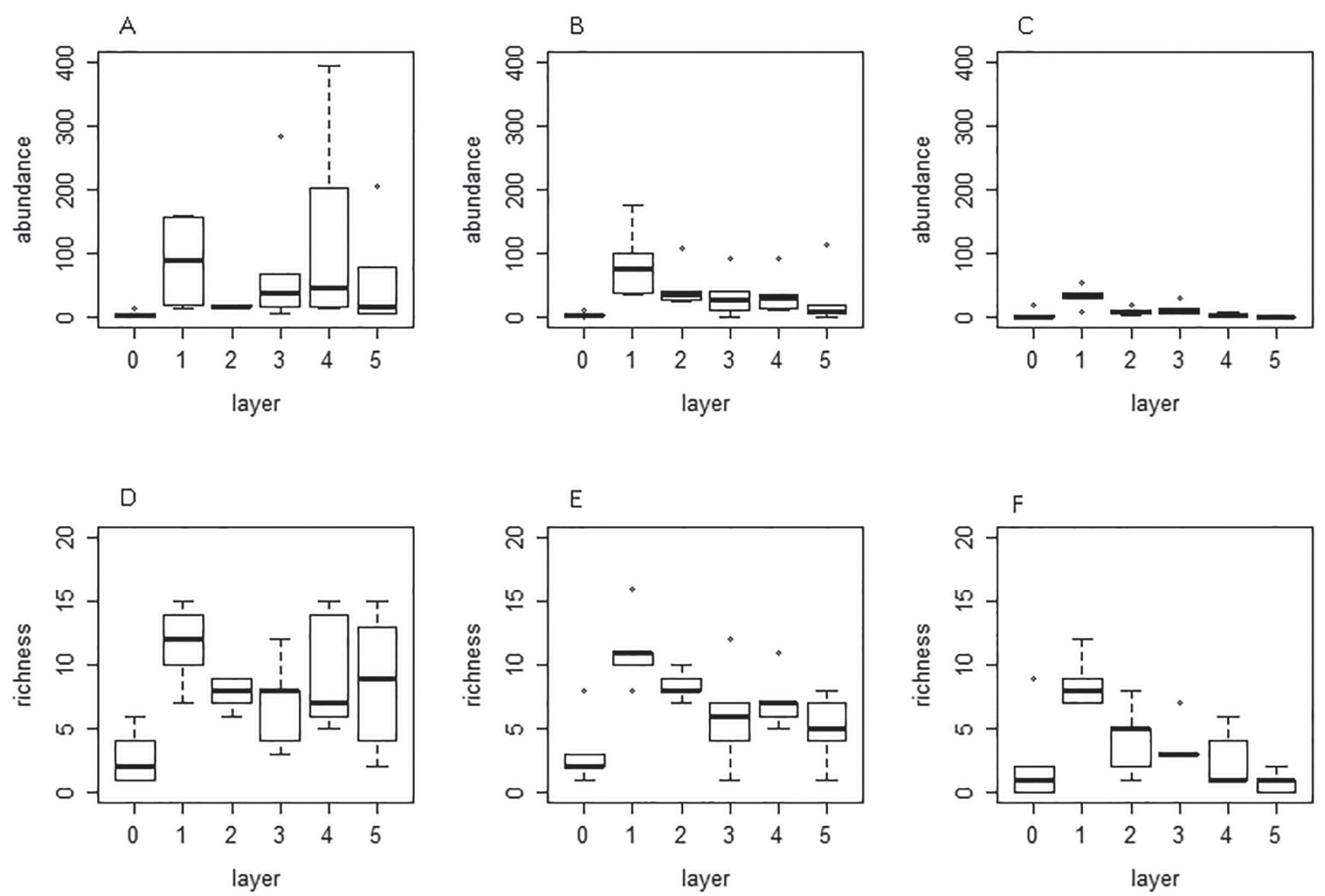

Figure 2. Distribution of abundance (A-C) and richness (D-F) of seeds and spores among positions (graphs from left to right: center, middle and border, respectively, also corresponding to more to less subject to inundation) and layers (0: litter; from 1 to $5: 2 \mathrm{~cm}$-thick layers until $10 \mathrm{~cm}$-depth) in floodable Grasslands of the Pantanal. Abundance of I. pedersenii (total of 3184 seedlings) was omitted on A-C to provide a more meaningful scale.

Table 2. Horizontal spatial distribution of propagules of soil seed and spore banks in floodable grasslands of the Pantanal wetland.

\begin{tabular}{|c|c|c|c|c|}
\hline & Center & Middle & Border & Total \\
\hline Total abundance & 4006 & 1169 & 314 & 5489 \\
\hline Relative abundance & 0.73 & 0.21 & 0.06 & 1 \\
\hline Average abundance and standard deviation & $799.80 \pm 1164.10$ & $235.20 \pm 138.58$ & $62.80 \pm 27.44$ & $\begin{array}{l}365.93 \pm \\
706.42-\end{array}$ \\
\hline Total richness & 37 & 31 & 26 & 44 \\
\hline Relative richness & 0.84 & 0.70 & 0.59 & 1 \\
\hline Average richness and standard deviation & $20.00 \pm 1.87$ & $17.40 \pm 1.52$ & $13.60 \pm 3.29$ & $\begin{array}{l}17.00 \\
\pm 3.48\end{array}$ \\
\hline Exclusive species & 7 & 3 & 3 & 13 \\
\hline$\%$ of common species & 2.63 & 3.23 & 3.85 & 2.27 \\
\hline$\%$ of near abundant species & 0.00 & 0.00 & 0.00 & 0 \\
\hline$\%$ of rare species & 97.37 & 96.77 & 96.15 & 97.73 \\
\hline $\begin{array}{c}\text { Average density (seeds and spores } / \mathrm{m}^{2} \text { ) } \\
\text { and standard deviation }\end{array}$ & $13878.47 \pm 20214.35$ & $4059.03 \pm 2422.90$ & $1090.28 \pm 476.31$ & 6343 \\
\hline $\begin{array}{l}\text { Average density }\left(\text { seeds } / \mathrm{m}^{2}\right) \\
\text { and standard deviation, excluded ferns }\end{array}$ & $\begin{array}{c}3777.78 \\
\pm 2352.37\end{array}$ & $\begin{array}{c}3045.14 \\
\pm 1326.43\end{array}$ & $\begin{array}{l}1010.42 \\
\pm 481.66\end{array}$ & 2611 \\
\hline
\end{tabular}


The vertical distribution of abundance of seed and spores in the banks (Fig. 2A-C; Tab. 3) differed among soil layers. There were less seeds and spores in the litter and in the deepest layer $(8-10 \mathrm{~cm})$ than in the other layers (Tab. 3). Litter layer samples showed a very low seed density (68 seedlings, $1.2 \%$ of total; Fig. 2, Tab. 3); it appears the litter layer is not an important seed stock, contrasting with reports for the arid shrublands of the Brazilian Caatinga (Costa \& Araújo 2003) and the seasonal Atlantic Forest (Souza et al. 2006). The low seed and spore density of the litter may be explained by a greater exposure to predators. Louda (1989) suggests that predation is a major source of seed bank depletion in upper soil layers, along with germination (Leck 1989). Likewise, the litter layer may show a lower seed density due to germination, in manner similar to how the first soil layer $(0-2 \mathrm{~cm})$ showed a lower density when compared to the second layer $(2-4 \mathrm{~cm})$.

In addition to it being more difficult for propagules to penetrate to the deepest layer, a major cause of the low density observed for this layer is non-viable seed, especially since in this layer seeds tend to be stocked for a longer period of time (Thompson et al. 1997), which leads to viability loss (Garwood 1989; Bekker et al. 1998). With the exception of the litter and first layer, and whereas the second soil layer $(2-4 \mathrm{~cm})$ showed the highest seed density, a trend of reduced density with soil depth was observed, as has been reported in several other studies (e.g. Bonis \& Lepart 1994; LópezMariño et al. 2000; Tesfaye et al. 2004; Luzuriaga et al. 2005).

Special consideration must be made to Isoetes pedersenii (Isoetaceae) that accounted for $~ 53 \%$ of the species of the seed and spore banks. When the abundance of this species was concentrated in the center of floodable sites and in the upper soil layers it contributed to an increase in the spatial variation of abundance. However, even when ferns are excluded from these data, and thus reverting to the more restrictive concept of seed bank (Baskin \& Baskin 2001), the interaction between inundation intensity (sample positions) and soil layers remained significant. Clearly this interaction, present even under the more restrictive concept of seed bank, reinforces the importance of inundation in structuring the abundance of seeds and spores in soil banks.

\section{Richness}

Thirty-eight species were found in most humid part of the grasslands studied-the center. Thirty-one and twenty-six species were recorded for the middle and border positions, respectively (Tab. 2). The first layer $(0-2 \mathrm{~cm})$ showed high species richness, greater than the litter and the other layers under $4 \mathrm{~cm}$ in depth. There were species exclusive to both sampling positions and to layers (Tab. 1 in supplemental material and Tabs. 2-3). A significant interaction was detected between the local richness of layers and flooding intensity (grassland position) $(\mathrm{z}=-3.942, \mathrm{p}<0.001)$, revealing the influence that inundation has on the richness of propagules of the soil bank, as was also detected for abundance.

There was no homogeneity in the distribution of richness relative to inundation (Fig. 2D-E). Additionally, inundation improved richness through dispersion of propagules and affected local life cycles of plants. Bigwood \& Inouye (1988) reported that seeds are frequently not uniformly distributed in a habitat and most seeds in the soil are clustered in an irregular manner (see also Thompson 1978 and Matlack \& Good 1990). In the floodable grassland sites of the Pantanal the seeds and spores showed a clear spatial pattern of being concentrated in the most humid parts of the grasslands, thus suggesting that flooding is central to the maintenance of soil seed and spore banks in these environments (Leck 1989).

Table 3. Vertical spatial distribution (depth of soil) of propagules of soil seed and spore banks in floodable grasslands of the Pantanal wetland. Layers: $\mathbf{0}$ - litter, $\mathbf{1}-0$ $-2 \mathrm{~cm}, 2-2-4 \mathrm{~cm}, 3-4-6 \mathrm{~cm}, 4-6-8 \mathrm{~cm}, 5-8-10 \mathrm{~cm}$-thick.

\begin{tabular}{|c|c|c|c|c|c|c|c|}
\hline Layers & 0 & 1 & 2 & 3 & 4 & 5 & Total \\
\hline Total abundance & 68 & 1603 & 1841 & 644 & 874 & 459 & 5489 \\
\hline Relative abundance & 0.01 & 0.29 & 0.33 & 0.12 & 0.16 & 0.08 & 1 \\
\hline $\begin{array}{l}\text { Average abundance and } \\
\text { standard deviation }\end{array}$ & $\begin{array}{c}4.53 \\
\pm 5.82\end{array}$ & $\begin{array}{c}107.47 \\
\pm 165.92\end{array}$ & $\begin{array}{c}122.13 \\
\pm 377.88\end{array}$ & $\begin{array}{c}42.93 \\
\pm 71.88\end{array}$ & $\begin{array}{c}58.27 \\
\pm 106.96\end{array}$ & $\begin{array}{c}30.60 \\
\pm 58.63\end{array}$ & $\begin{array}{c}60.99 \\
\pm 178.03\end{array}$ \\
\hline Total richness & 19 & 34 & 27 & 23 & 26 & 23 & 44 \\
\hline Relative richness & 0.43 & 0.77 & 0.61 & 0.52 & 0.59 & 0.52 & 1 \\
\hline $\begin{array}{l}\text { Average richness and } \\
\text { standard deviation }\end{array}$ & $\begin{array}{c}2.80 \\
\pm 2.78\end{array}$ & $\begin{array}{l}10.33 \\
\pm 2.87\end{array}$ & $\begin{array}{c}6.73 \\
\pm 2.58\end{array}$ & $\begin{array}{c}5.73 \\
\pm 3.28\end{array}$ & $\begin{array}{c}6.40 \\
\pm 4.24\end{array}$ & $\begin{array}{c}4.60 \\
\pm 4.44\end{array}$ & $\begin{array}{c}6.1 \\
\pm 4.06\end{array}$ \\
\hline Exclusive species & 2 & 6 & 3 & 0 & 1 & 1 & 13 \\
\hline$\%$ of abundant species & 0 & 2.94 & 3.70 & 4.35 & 3.85 & 4.35 & 2.27 \\
\hline$\%$ of moderate species & 0 & 0 & 0 & 0 & 0 & 0 & 0 \\
\hline$\%$ rare species & 100 & 97.06 & 96.30 & 95.65 & 96.15 & 95.65 & 97.78 \\
\hline $\begin{array}{l}\text { Average density (seeds } \\
\text { and spores } / \mathrm{m}^{2} \text { ) and } \\
\text { standard deviation }\end{array}$ & $\begin{array}{c}78.40 \\
+100.93\end{array}$ & $\begin{array}{c}1854.93 \\
+2881.59\end{array}$ & $\begin{array}{c}2119.87 \\
\pm 6560.51\end{array}$ & $\begin{array}{c}744.87 \\
\pm 1247.71\end{array}$ & $\begin{array}{c}1011.07 \\
\pm 1856.98\end{array}$ & $\begin{array}{c}530.80 \\
\pm 1017.78\end{array}$ & 6478 \\
\hline
\end{tabular}


Among the 32 species that occurred in at least two sampling positions (Tab. 1 in supplemental material), 24 showed significantly higher abundance in the center. The longer flooding in the center of the grassland sites can increase the number of different aquatic macrophytes that complete their life cycle and produce seeds (Casanova \& Brock 2000). Furthermore, the more humid soil seems to contribute to the long-term conservation of seeds and spores. As stated by Castro et al. (2004), not all seeds have the ability to tolerate desiccation without viability loss.

\section{Conclusions}

Seed and spore banks in floodable grassland sites of the Pantanal showed clumped distributions of seeds and spores, with a concentration of abundance and richness in the more flood-prone center and in soil layers up to $4 \mathrm{~cm}$ deep (excluding litter). Therefore, it is clear that these center microsites must be considered in management plans, since they are locations of the greatest species richness and abundance. The species richness recorded in this study is almost certainly a minimal estimate since an almost total dominance by aquatic phase species was recorded. The horizontal spatial distribution of seeds, and the specific composition of the layers, suggests that flooding is a key factor in determining propagule soil bank constitution in Brazilian Pantanal grasslands in the same manner as it is for established vegetation.

\section{Acknowledgments}

We thank the managers of RPPN-SESC Pantanal for staffing our study. Special thanks go to Fernando Henrique Barbosa da Silva for accompanying the whole research endeavor. We thank Arnildo Pott and Vali Pott for their expertise in plant identification, Jerry M.F. Penha for his skill with statistical analysis, Felipe F. Curcio for reviewing the English text, and Pedro V. Eisenlohr and Victor L. Landeiro for providing helpful comments. This study was supported by PELD (Programa de Estudos Ecológicos de Longa Duração), INAU (Instituto Nacional de Ciência e Tecnologia em Áreas Úmidas) and CNPq (Conselho Nacional de Desenvolvimento Científico e Tecnológico).

\section{References}

Abdon MM, Silva JS, Pott VJ, Pott A, Silva MP. 1998. Utilização de dados analógicos do Landsat-TM na discriminação da vegetação de parte da sub-região da Nhecolândia no Pantanal. Pesquisa Agropecuária Brasileira 33 (número especial): 1799-1813.

Araújo MM, Longhi SJ, Barros PLC, Brena DA. 2004. Caracterização da chuva de sementes, banco de sementes do solo e banco de plântulas em floresta estacional decidual ripária de Cachoeira do Sul, RS, Brasil. Scientia Florestalis 66: 128-141.

Araújo MM, Oliveira FA, Vieira, ICG, Barros PLC, Lima CAT. 2001. Densidade e composição florística do banco de sementes do solo de florestas sucessionais na região do baixo rio Guamá, Amazônia. Scientia Florestalis 59: 115-130.

Bao F, Pott A, Ferreira FA, Arruda R. 2014. Soil seed bank of floodable native and cultivated grassland in the Pantanal wetland: effects of flood gradient, season and species invasion. Brazilian Journal of Botany 7: 239-250.

Baskin CC, Baskin JM. 2001. Germination Ecology of Seeds in the Persistent Seed Bank. In: Baskin CC, Baskin JM. (eds.) Seeds, ecology, biogeography, and evolution of dormancy and germination. New York, Academic Press. p. 133-179.

Baskin CC, Baskin JM. 2004. A classification system for seed dormancy. Seed science Research 14: 1-16.

Bekker RM, Bakker JP, Grandin U, et al. 1998. Seed size, shape and vertical distribution in the soil: indicators of seed longevity. Functional Ecology 12: 834-842.

Bigwood DW, Inouye DW. 1988. Spatial pattern analysis of seed banks: An improved method and optimized sampling. Ecology 69: 497-507.

Bonis A, Lepart J. 1994. Vertical structure of seed banks and the impact of depth of burial on recruitment in two temporary marshes. Vegetatio 112: 127-139.

Borghetti F. 2004. Dormência Embrionária. In: Ferreira AG, Borghetti F. (eds.) Germinação: do básico ao aplicado. Porto Alegre, Artmed. p. 109-123.

Butler BJ, Chazdon RL. 1998. Species richness, spatial variation, and abundance of the soil seed bank of a secondary tropical rain forest. Biotropica 30: 214-222.

Capon SJ, Brock MA. 2006. Flooding, soil seed bank dynamics and vegetation resilience of a hydrologically variable desert floodplain. Freshwater Biology 51: 206-223.

Cardoso EL, Crispim SMA, Rodrigues CAG, Barioni Junior W. 2000. Biomassa aérea e produção primária do estrato herbáceo em campo de Elyonurus muticus submetido à queima anual, no Pantanal. Pesquisa Agropecuária Brasileira 35: 1501-1507.

Casanova MT, Brock MA. 2000. How do depth, duration and frequency of flooding influence the establishment of wetland plant communities? Plant Ecology 147: 237-250.

Castro RD, Bradford KJ, Hilhorst HWM. 2004. Desenvolvimento de sementes e conteúdo de água. In: Ferreira AG, Borghetti F. (eds.) Germinação: do básico ao aplicado. Porto Alegre, Artmed. p. 51-67.

Cheke AS, Nanakorn W, Ynakoses C. 1979. Dormancy and dispersal of seeds of secondary forest species under the canopy of a primary tropical rainforest in northern Thailand. Biotropica 11: 88-95.

Costa RC, Araújo FS. 2003. Densidade, germinação e flora do banco de sementes no solo, no final da estação seca, em uma área de caatinga, Quixadá, CE. Acta Botanica Brasilica 17: 259-264.

Fenner M, Thompson K. 2005. Soil Seed Banks. In: Fenner M, Thompson K. (eds.) The Ecology of Seeds. Cambridge, Cambridge University Press. p. 76-96.

Garwood NC. 1989. Tropical soil seed banks: a review. In: Leck MA, Parker VT, Simpson RL. (eds.) Ecology of Soil Seed Bank. San Diego, Academy Press. p. 149-210.

Hasenack H, Cordeiro JLP, Hofmann GS. 2003. O clima da RPPN SESC Pantanal: relatório técnico. Porto Alegre, UFRGS.

Hölzel N, Otte A. 2001. The impact of flooding regime on the soil seed bank of flood-meadows. Journal of Vegetation Science 12: 209-218.

Ikeda FS, Mitja D, Vilela L, Silva JCS. 2008. Banco de sementes em cerrado sensu stricto sob queimada e sistemas de cultivo. Pesquisa Agropecuária Brasileira 43: 667-673.

Jalili A, Hamzeh'ee B, Asri Y, et al. 2003. Soil seed banks in the Arasbaran Protected Area of Iran and their significance for conservation management. Biological Conservation 109: 425-431.

Köppen W. 1948. Climatología: con un estudio de los climas de la tierra. Ciudad del Mexico, Fondo de Cultura Económica.

Leal EC, Vieira ICG, Kato MSA. 2006. Banco de sementes em sistemas de produção de agricultura com queima e sem queima no município de Marapanim, Pará. Boletim do Museu Paraense Emilio Goeldi: Ciências Naturais 1: 19-29.

Leck MA. 1989. Wetland seed banks. In: Leck MA, Parker VT, Simpson RL. (eds.) Ecology of Soil Seed Bank. San Diego, Academy Press, Inc. p. 283-308. 
López-Mariño A, Luis-Calabuig E, Fillat F, Bermúdez FF. 2000. Floristic composition of established vegetation and the soil seed bank in pasture communities under different traditional management regimes. Agriculture Ecosystems and Environment 78: 273-282.

Louda SM. 1989. Predation in the dynamics of seed regeneration. In: Leck MA, Parker VT, Simpson RL. (eds.) Ecology of Soil Seed Bank. San Diego, Academy Press. p. 25-51.

Luzuriaga AL, Escudero A, Olano JM, Loidi J. 2005. Regenerative role of seed banks following an intense soil disturbance. Acta Oecologica 27: 57-66.

Maia FC, Medeiros RB, Patta-Pillar V, Focht T. 2004. Soil seed bank variation patterns according to environmental factors in a natural grassland. Revista Brasileira de Sementes 26: 126-137.

Matlack GR, Good RE. 1990. Spatial heterogeneity in the soil seed bank of a mature coastal plain forest. Bulletin of the Torrey Botanical Club 112: $143-152$.

Melo ACG, Durigan G, Gorenstein MR. 2007. Efeito do fogo sobre o banco de sementes em faixa de borda de floresta estacional semidecidual, SP, Brasil. Acta Botanica Brasilica 21: 927-934.

Middleton B. 2000. Hydrochory, seed banks, and regeneration dynamics along the landscape boundaries of a forested wetland. Plant Ecology 146: 169-184.

Nunes da Cunha C, Junk WJ, Leitão-Filho HF. 2007. Woody vegetation in the Pantanal of MatoGrosso, Brazil: a preliminary tipology. Amazoniana, XIX: 159-184.

Nunes da Cunha C, Rawiel P, Wantzen KM, Junk WJ, Lemes do Prado A. 2006. Mapping and characterization of vegetation units by means of Landsat imagery and management recommendations for the Pantanal of Mato Grosso (Brazil), north of Poconé. Amazoniana XIX: 1-32.

Pagotto MA, Silveira RML, Nunes da Cunha C, Fantin-Cruz I. 2011. Distribution of Herbaceous Species in the soil seed bank of a flood seasonality area, northern Pantanal, Brazil. International Review of Hydrobiology 96: 149-163.

Peterson JE, Baldwin AH. 2004. Seedling emergence from seed banks of tidal freshwater wetlands: response to inundation and sedimentation. Aquatic Botany 78: 243-254.

Pott VJ, Pott A. 2000a. Distribuição de macrófitas aquáticas no Pantanal. In: Anais do Simpósio sobre Recursos Naturais e Sócio-econômicos do Pantanal: Os desafios do novomilênio, 3, Corumbá. Brasília, EMBRAPA-CPAP.

Pott VJ, Pott A. 2000b. Plantas Aquáticas do Pantanal. Brasília, EMBRAPACPAP.

Prado AL, Heckman CW, Martins FR. 1994. The seasonal succession of biotic communities in wetlands of the tropical wet-and-dry climatic zone: II. The aquatic macrophyte vegetation in the Pantanal of Mato Grosso, Brazil. Internationale Revue der gesamten Hydrobiologie und Hydrographie 79: 569-589.
Rebellato L, Nunes da Cunha C. 2005. Efeito do "fluxo sazonal mínimo da inundação" sobre a composição e estrutura de um campo inundável no Pantanal de Poconé, MT, Brasil. Acta Botanica Brasilica 19: 789-799.

Rice KJ. 1989. Impacts of Seed Banks on Grassland Community Structure and Population Dynamics. In: Leck MA, Parker VT, Simpson RL. (eds.) Ecology of Soil Seed Bank. San Diego, Academy Press. p. 212.-230.

Schessl M. 1999. Floristic composition and structure of floodplain vegetation in northern Pantanal of Mato Grosso, Brazil. Phyton 39: 303-336.

Silva JC, Figueiredo DM. 1999. Variação limnológica das baías de Chacororé e Sá Mariana, Pantanal Mato-grossense, Mato Grosso (MT). Revista Mato-Grossense de Geografia 3-4: 57-75.

Silva JSV, Abdon MM. 1998. Delimitação do Pantanal Brasileiro e suas sub-regiões. Pesquisa Agropecuária Brasileira 33: 1703-1711.

Silveira RM, Weiss B. 2014. Evidence for herbaceous seed dispersal by small-bodied fishes in a Pantanal seasonal wetland. Brazilian Journal of Biology. 74: 588-96.

Simpson RL, Leck MA, Parker VT. 1989. Seed banks: General concepts and methodological issues. In: Leck MA, Parker VT, Simpson RL. (eds.) Ecology of Soil Seed Bank. San Diego, Academy Press. p. 3-8.

Souza PA, Venturin N, Griffith JJ, Martins SV. 2006. Avaliação do banco de sementes contido na serapilheira de um fragmento florestal visando a recuperação de áreas degradadas. Cerne 12: 56-67.

Tesfaye G, Teketay D, Assefa Y, Fetene M. 2004. The impact of fire on the soil seed bank and regeneration of Harenna forest, southeastern Ethiopia. Mountain Research and Development 24: 354-361.

Thompson K. 1978. The occurrence of buried viable seeds in relation to environmental gradients. Journal of Biogeography 5: 425-430.

Thompson K. 1992. The functional ecology of seed banks. In: Fenner M. (ed.) Seeds: the ecology of regeneration in plant communities. United Kingdom, C.A.B. International.

Thompson K, Bakker J, Bekker R. 1997. The soil seed banks of North West Europe: methodology, density and longevity. Cambridge, Cambridge University Press.

Tuffi-Santos LD, Santos IC, Oliveira CH, Santos MV, Ferreira FA, Queiroz DS. 2004. Levantamento fitossociológico em pastagens degradadas sob condições de várzea. Planta Daninha 22: 343-349.

Ungar IA, Woodell SRJ. 1996. Similarity of seed banks to aboveground vegetation in grazed and ungrazed salt marsh communities on the Gower peninsula, South Wales. International Journal of Plant Sciences 157: 746-749.

Valk AG. 2013. Seed banks of drained floodplain, drained palustrine, and undrained wetlands in Iowa, USA. Wetlands 33: 183-190.

Valk AG. Rosburg TR. 1997. Seed bank composition along a phosphorus gradient in the northern Florida Everglades. Wetlands 17: 228-236.

Zar JM. 1999. Biostatistical Analysis. 4th. edn. New Jersey, Prentice Hall. 